\title{
Evaluation of Lifetime Cancer Risk in Some Vegetables and Soil Samples in Two Main Cities in Ogun State: Human and Ecological Risk
}

Omolola E. OMOTOSHO ( $\sim$ lola.omotosho@covenantuniversity.edu.ng )

Covenant University

Olusegun Akinola

Covenant University

Maxwell Omeje

Covenant University

Temidayo OMOTOSHO

Covenant University

\section{Sarah Evbuomwan}

Covenant University

\section{Moses Emetere}

Covenant University

\section{Femi Ayoade}

Redeemer's University

\section{Babatunde Rabiu}

Centre of Atmospheric Research, National Space Research and Development Agency, Anyigba, Kogi State

\section{Research Article}

Keywords: Food safety, Natural Radionuclides, Toxicity, Soil, Leafy vegetables

Posted Date: February 14th, 2022

DOI: https://doi.org/10.21203/rs.3.rs-1226112/v1

License: (c) (i) This work is licensed under a Creative Commons Attribution 4.0 International License.

Read Full License 


\section{EVALUATION OF LIFETIME CANCER RISK IN SOME VEGETABLES AND SOIL SAMPLES IN TWO MAIN CITIES IN OGUN STATE: HUMAN AND ECOLOGICAL RISK}

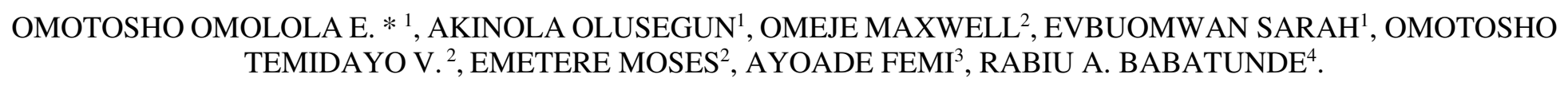

${ }^{1}$ Department of Biochemistry, Covenant University, P.M.B 1023, Km 10, Idiroko road, Canaan land, Ota, Ogun State, Nigeria.

${ }^{2}$ Department of Physics, Covenant University, P.M.B 1023, Km 10, Idiroko road, Canaan land, Ota, Ogun State, Nigeria.

${ }^{3}$ Department of Biological Sciences, Redeemer's University, P.M.B. 230, Gbongan/Osogbo Expressway, Ede, Osun State, Nigeria.

${ }^{4}$ Centre of Atmospheric Research, National Space Research and Development Agency, Anyigba, Kogi State, Nigeria.

\section{*OMOTOSHO OMOLOLA ELIZABETH}

lola.omotosho@covenantuniversity.edu.ng

$+2348034289892$

\section{Abstract}

The spate of health challenges via the ingestion of radionuclides is still of concern especially in regions that have no clear documentation of background of radioactive sources. The present study evaluated the activity concentrations of naturally occurring radioactive nuclides in plants and their corresponding soil collected at Ibeshe and Covenant University community areas of Ogun State, Nigeria. The activity concentrations and other radiological risks from consuming the leafy vegetables were also estimated. The results show that the mean concentration of ${ }^{226} \mathrm{Ra},{ }^{232} \mathrm{Th},{ }^{40} \mathrm{~K}$ in the agricultural soil were found to be $24.18 \pm 2.31,20.93 \pm 2.27,20.95 \pm 1.9$ for Ibeshe and $58.76 \pm 4.84$, $26.06 \pm 1.93,33.87 \pm 2.23$, respectively for Covenant University. Whereas, for the leafy vegetables, the mean concentration of ${ }^{226} \mathrm{Ra},{ }^{232} \mathrm{Th}$, ${ }^{40} \mathrm{~K}$ were found to be $5.02 \pm 0.9,7.98 \pm 1.70,427.82 \pm 29.75$ for Ibeshe and $17.57 \pm 2.35,22.19 \pm 3.0$, and $424.17 \pm 25.15$ for Covenant University Community. In comparison, all these values are within the recommended limits of 32.00 and $45.00,420.00$, Bqkg-1for ${ }^{226} \mathrm{Ra}$, ${ }^{232} \mathrm{Th},{ }^{40} \mathrm{~K}$ according to the United Nations Scientific Committee on the Effect of Atomic Radiation (UNCEAR) except the mean value 
for Covenant University soil for ${ }^{232} \mathrm{Th}$ which is slightly higher. The values obtained were comparable to the internationally recommended values. The mean value for excess lifetime cancer risk (ELCR) for Ibeshe North is 31.08, while that of Canaanland (CU) is 239.03, respectively is lower than the recommended limits of other published papers $1.72 \times 10^{4}$ according to International Commission on Radiological Protection (ICRP). These lower radiological risks indicate apparently that the chemical carcinogenic pollutants in the samples may be the major risk, inducing chemical parameters in the study area. This study will serve as a baseline data for any radiologically induced diseases. Significantly, it will serve as a baseline data for any radiologically induced diseases from vegetables in Nigeria and suggests further research on chemical toxicity risks on the same samples.

Keywords: Food safety; Natural Radionuclides; Toxicity; Soil; Leafy vegetables

\subsection{Introduction}

Natural radionuclides such as ${ }^{238} \mathrm{U},{ }^{232} \mathrm{Th}$, their descendants, and non-systems ${ }^{40} \mathrm{~K}$ are generally spreading on Earth. A significant amount of these radionuclides is present in many mineral locks, including granite [9]. Therefore, granite can have significant amounts of natural radionuclides such as ${ }^{238} \mathrm{U},{ }^{232} \mathrm{Th}$, its offspring, and non-class ${ }^{40} \mathrm{~K}[22,28,31]$. The concentration of these radionuclides does not spread uniformly on the specific granite bricks. The naturally existing radionuclides that block ionizing radiation are present in the environment. Invariably they are present on the ground, rocks, sand, water, and other land minerals for architecture and construction purposes [22, $34,21,32,24]$. These radionuclides release hazardous ionized radiation known to cause cancer and other effects of radiation health and the critical body. $[5,22,23,7,28]$. Radionuclides in mineral soils, such as granite, enter through the waterways (drinking water) and possibly could be incorporated into plants, therefore, there is the possibility of a greater redistribution in the dietary chain. Consequently, they can eventually go to humans through food chains and may present an environmental threat to the health of the local population. Therefore, information on these radionuclides in the environment is basic to estimate the level of public exposure to ionizing radiation. Research on the level of natural radionuclides and their offspring are carried out in various parts of Nigeria [11, 3, 2, 15, 4, 30, 32, 14, $25,1]$. The absorption of radionuclides by soil occurs in many ways. The prediction of radionuclides, heterogeneity and land 
composition, and radionuclide predictions are some problems. Radiation protection of the public via ingestion through foodstuff has generated more interest owing to the spate of diseases and infant deformation that ensued from the release of radiation exposure to the public in any environment. Several studies had documented radioactive concentrations within their locality to aid health workers and environmental experts on salient decisions to protect the public. The aim of this present study was to ascertain the signature of the carcinogenic risks due to the presence of naturally occurring radionuclides in selected vegetables and soil samples from some parts of Ota, Ogun State, and the potential health effects to the consumers.

\subsection{Geology and Geographical Location of the Study Area}

The study areas of this work covered Ibeshe community and Covenant University. Ibeshe is located in Yewa North Local government of Ogun State while Covenant University (CU) is located in Ado Odo/ Ota Local Government area of Ogun State. Ibeshe is home to Dangote Cement Factory which is the largest cement factory in Sub-Saharan Africa. Covenant University is based in Ota which is a densely populated city in Ogun State with a lot of urban development and factory presence.

\subsection{Geology and Geographical Location of the Study Area}

The study area is located within the eastern Dahomey Basin in Ogun State, Nigeria. The coordinates are within Latitude and Longitude of $6.6726^{\circ} \mathrm{N}, 3.1612^{\circ} \mathrm{E}$ and $6.9528^{\circ} \mathrm{N}, 3.0388^{\circ} \mathrm{E}$ for Covenant University area and Ibeshe community respectively. The site is characterized by Late Cretaceous to Early Tertiary sedimentary and basement complex rocks [17, 18]. The Abeokuta group formation, Imo group formation, Ewekoro formation, Ilaro formation, Benin formation and Oshosun formation are stratigraphically represented in Ogun State's sedimentary. The Ise, Afowo, and Araromi formations are part of the Abeokuta group, which is located above the basement complex. The Ewekoro, Oshosun, and Ilaro groups are all overlain by the Benin formation group of coastal plain sands, which is overlain by the Abeokuta Formation group [18,19] as shown in Figure 1. 


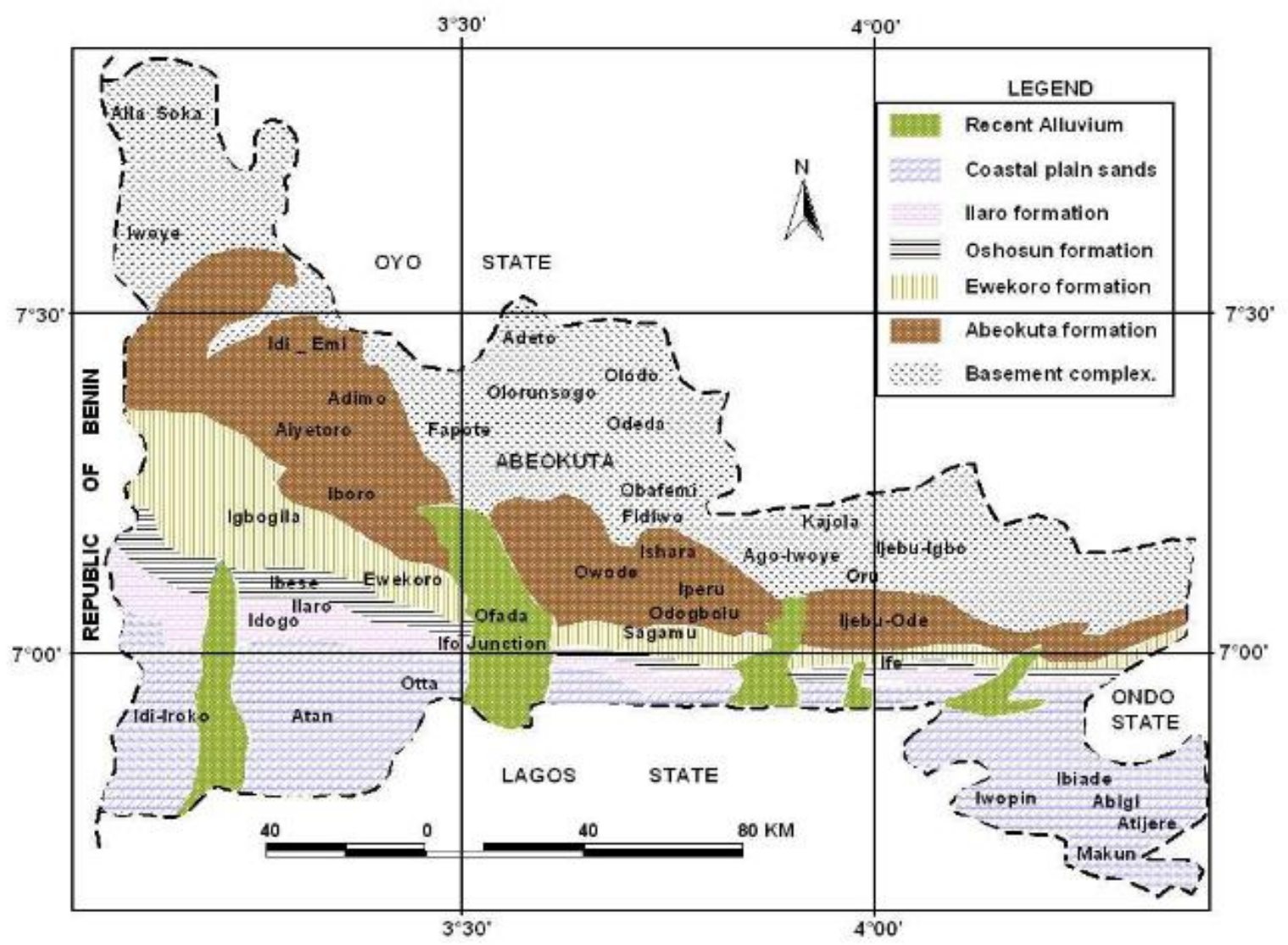

63 Figure 1: Geologic Map of the Study Area (Source: Nigeria Geological Survey Agency)

$64 \quad 3.0 \quad$ Materials and Methods

$65 \quad 3.1 \quad$ Sample Collection and Preparation

66 Samples of Cnidoscolous aconitifolius (Chaya leaves), Telfaria occidentalis (Fluted pumpkin), Corchorus olitorius (Jew's mallow), 67 Moringa Oleifera (Moringa), Talinum triangulare (Gbure) and Moringa oleifera (Moringa) were cultivated in these two locations, 
Covenant University area and Ibeshe. The plants (leaves and stems) were collected by permission from the farmers in the areas as shown in Figure 1, the plants were identified by Dr. Popoola, a Botanist in the Department of Biological Sciences, Covenant University, Ota, Ogun State, Nigeria. The plants were collected and washed with distilled water and chopped into minute sizes before they were put in an oven and dried at $80^{\circ} \mathrm{C}$ according to [6] for four days, crushed to powder and sieved to collect the appropriate sizes through a sieve mesh of $250 \mu \mathrm{m}$. They were sealed for four weeks to allow radioactive equilibrium to be reached. Also, soil samples which were collected from the locations where the leafy vegetables were collected were oven dried, crushed to powder and sieved the same way as the vegetable and sealed for four weeks secular equilibrium.

High Purity Germanium (HPGe) gamma ray detector with $10 \mathrm{~cm}$ x $10 \mathrm{~cm}$ thick lead shielding on all sides with inner Cu and Sn lining, to reduce the background activity to about $95 \%$. The efficiency of the $\Upsilon$-ray spectrometer was $52.3 \%$ relatively to $\Upsilon$-ray spectrometer. Minimum detection limit of the g-ray spectrometer was $6.35,3.25$ and $2.15 \mathrm{Bqkg}-11$ for ${ }^{226} \mathrm{Ra},{ }^{232} \mathrm{Th}$ and ${ }^{40} \mathrm{~K}$ respectively. The choice of gamma-ray peaks of the radionuclides to be used for measurements was made considering the fact that the $\mathrm{NaI}$ (Tl) detector used in this study had a modest energy resolution. This was to ensure that the photons emitted by the radionuclides would only be sufficiently discriminated if their emission probability and their energy were high enough, and the surrounding background continuum low enough. Therefore, the activity concentration of ${ }^{214} \mathrm{Bi}$ was chosen to provide an estimate of ${ }^{226} \mathrm{Ra}\left({ }^{238} \mathrm{U}\right)$ in the samples, while that of the daughter radionuclide ${ }^{208} \mathrm{Ti}$ was chosen as an indicator of ${ }^{228} \mathrm{Th}\left({ }^{232} \mathrm{Th}\right)$. Potassium-40 was determined by measuring the $1460 \mathrm{KeV}$ emitted during its decay.

\subsection{Calculation of Radium Equivalent Activity Raeq and External Radiation Hazards Hex}

The radium equivalent (Raeq) activity allows a single index or number to describe the gamma output from different mixtures of ${ }^{238} \mathrm{U}$, ${ }^{232} \mathrm{Th}$, and ${ }^{40} \mathrm{~K}$ in a sample.

$\mathrm{Ra}_{\mathrm{eq}}=\mathrm{A}_{\mathrm{RA}}+1.43 \mathrm{~A}_{\mathrm{Th}}+0.077 \mathrm{~A}_{\mathrm{K}}$ 
89

$D_{c}=0.462 \mathrm{~A}\left({ }^{238} \mathrm{U}\right)+0.604 \mathrm{~A}\left({ }^{232} \mathrm{Th}\right)+0.0417 \mathrm{~A}\left({ }^{40} \mathrm{~K}\right)$

\subsubsection{Estimation of the annual effective dose rate (AEDR)}

94

95

96

97

98

99

100

$I \gamma=\frac{C_{R a}}{300 B q K g^{-1}}+\frac{C_{T h}}{200 B q K g^{-1}}+\frac{C_{K}}{3000 B q K g^{-1}}$

101

102

\subsubsection{Calculation of the external gamma dose rate}

$\mathrm{AEDR}=D_{c}\left(\mathrm{nGy} \mathrm{h}^{-1}\right) \times 8760 \mathrm{~h} \times 0.2 \times 0.7 \mathrm{~Sv} \mathrm{~Gy}^{-1} \times 10^{-3}$

\subsubsection{Gamma Activity Index Representations $\left(I_{\gamma}\right)$} to be negligible

\subsubsection{Alpha Index $(\mathrm{I} \alpha)$}

$$
I \alpha=\frac{C_{R a}}{200 B q K g^{-1}}
$$

Determination of the external gamma dose was calculated using the following equation by [9] by using equation 3

The estimation of the annual effective dose rate is estimated using equation 4 [28]

The gamma index (I $\gamma$ ) was used to estimate the gamma radiation hazard associated with the natural radionuclide in specific investigated samples. The representative gamma index was estimated using Equation 7 [8, 29]. It should be less than unity for the radiation hazard 


\subsubsection{Activity Utilization Index (AUI)}

106 The use of the utilization activity index (UAI) for soil can be estimated through the sum of the radionuclides such as ${ }^{238} \mathrm{U}^{232}$,Th and ${ }^{40} \mathrm{~K}$ 107 and this can be estimated by the use of equation 7 to be the activity in a unit of mass $\left(\mathrm{Bqkg}^{-1}\right)$ [16].

$108 \quad A U I=\left(\frac{C_{R a}}{50 \mathrm{Bqkg}-1}\right) f R a+\left(\frac{C_{T h}}{50 \mathrm{Bqkg}-1}\right) f T h+\left(\frac{C_{K}}{500 \mathrm{Bqkg}-1}\right) f k$

\subsubsection{Excess Lifetime Cancer Risk (ELCR)}

$110 \mathrm{AED}$ is the annual equivalent dose equivalent, $\mathrm{DL}$ is the average duration of life (estimated to 70 years), and RF is the risk factor (S/v), 111 for stochastic effects, ICRP uses RF as 0.05 for public [8]. The recommended limit for ELCR is $0.2 \times 10^{3}$ [29] below which there is no 112 cancer risk to the populace.

$113 E L C R=A E D R X D L X F$

\section{$114 \quad 3.3 \quad$ STATISTICAL ANALYSIS}

115 Statistical significance was determined by two-way analysis of variance (ANOVA). For all statistical tests, data are expressed as mean $116 \pm$ standard error of mean $(\mathrm{SEM}) ; P<0.05$ was considered significant.

\section{$117 \quad 4.0 \quad$ Results and Discussion}

$118 \quad 4.1 \quad$ Radioactivity Level of ${ }^{232} \mathrm{Th},{ }^{40} \mathrm{~K}$ and ${ }^{226} \mathrm{Ra}$ in the Vegetable and Soil Samples 
119 The radioactivity concentrations of ${ }^{226} \mathrm{Ra},{ }^{232} \mathrm{Th}$, and ${ }^{40} \mathrm{~K}$ for leafy vegetables and soil samples are presented in Tables 1 and 2 . Results

120 of the activity concentrations of radionuclide contents in the soil and leafy vegetables at Covenant University and Ibeshe ranged between 121 ( $\left.\mathrm{Th}^{-232}\right)$ 14.40-45.09, $\left(\mathrm{K}^{-40}\right)$ 9.09-38.82, $\left(\mathrm{Ra}^{-226}\right)$ 13.74-31.56. Covenant University $\left(\mathrm{Th}^{-232}\right)$ 40.20-76.47, $\left(\mathrm{K}^{-40}\right)$ 14.13-30.84, $\left(\mathrm{Ra}^{-226}\right)$ 122 23.23-43.61, leafy vegetables Ibeshe $\mathrm{Ra}^{-226} 0.75-11.89,\left(\mathrm{Th}^{-232}\right)$ 0.81-20.17, $\mathrm{K}^{-40} 191.06-709.88, \mathrm{CU}\left(\mathrm{Ra}^{-226}\right) 10.83-31.34,\left(\mathrm{Th}^{-232}\right) 7.58-$ 123 39.50, $\left(\mathrm{K}^{-40}\right)$ 112.69-939.30. Mean values were estimated to be Ibeshe $\left(\mathrm{Th}^{-232}\right) 24.18,\left(\mathrm{~K}^{-40}\right) 20.93,\left(\mathrm{Ra}^{-226}\right) 20.95, \mathrm{CU}\left(\mathrm{Th}^{-232}\right) 58.76, \mathrm{~K}^{-}$ 12440 21.71, $\left(\mathrm{Ra}^{-226}\right)$ 33.87. Covenant University soil was higher than the mean value of the World average standard values of 35, 30, and 400 Bqkg-1respectively except CU soil which was 58.76. Considering the collective statistical analysis presented in this study, it was observed that the absorption of radionuclide in different plants depends on the background radionuclide concentrations, absorption mechanism in plants, and sorption ability of the plants in soil-water interaction.

128

129 Table 1-The Radioactivity Levels of ${ }^{232} \mathrm{Th},{ }^{40} \mathrm{~K}$ and ${ }^{226} \mathrm{Ra}$ in the soil samples for Covenant University and Ibeshe

\begin{tabular}{|c|c|c|c|c|}
\hline $\mathbf{S} / \mathbf{N}$ & Sample codes & $\mathrm{Th}^{-232}\left(\mathrm{Bqkg}^{-1}\right)$ & $\mathrm{K}^{-40}\left(\mathrm{Bqkg}^{-1}\right)$ & $\mathbf{R a}^{-226}$ \\
\hline 1 & $\begin{array}{l}\text { Telfaria } \\
\text { occidentalis } \\
\text { (Ibeshe) }\end{array}$ & $25.56 \pm 1.43$ & $9.09 \pm 1.41$ & $23.23 \pm 1.37$ \\
\hline 2 & $\begin{array}{l}\text { Corchorous } \\
\text { olitorus (Ibeshe) }\end{array}$ & $22.74 \pm 1.68$ & $38.82 \pm 3.33$ & $18.88 \pm 1.60$ \\
\hline 3 & $\begin{array}{l}\text { Cnidoscolous } \\
\text { aconitifolius } \\
\text { (Ibeshe) }\end{array}$ & $14.55 \pm 2.06$ & $18.16 \pm 3.29$ & $17.56 \pm 2.28$ \\
\hline 4 & $\begin{array}{l}\text { Moringa oleifera } \\
\text { Ibeshe }\end{array}$ & $14.40 \pm 1.48$ & $14.54 \pm 2.51$ & $13.74 \pm 1.44$ \\
\hline 5 & $\begin{array}{l}\text { Manihot } \\
\text { esculenta } \\
\text { (Ibeshe) }\end{array}$ & $45.09 \pm 3.44$ & $24.61 \pm 1.58$ & $31.56 \pm 1.67$ \\
\hline
\end{tabular}




\begin{tabular}{|c|c|c|c|c|}
\hline 6 & $\begin{array}{l}\text { Talicum } \\
\text { fruticosum } \\
\text { Ibeshe }\end{array}$ & $22.71 \pm 3.77$ & $20.33 \pm 1.53$ & $20.70 \pm 3.04$ \\
\hline & MEAN & $24.18 \pm 2.31$ & $20.93 \pm 2.27$ & $20.95 \pm 1.9$ \\
\hline 1 & $\begin{array}{l}\text { Telfaria } \\
\text { occidentalis CU }\end{array}$ & $56.14 \pm 3.41$ & $14.13 \pm 1.70$ & $39.49 \pm 2.08$ \\
\hline 2 & $\begin{array}{l}\text { Corchorous } \\
\text { olitorius CU }\end{array}$ & $76.47 \pm 8.03$ & BDL & $29.78 \pm 4.05$ \\
\hline 3 & $\begin{array}{l}\text { Cnidoscolous } \\
\text { aconitifolius } \\
\text { (CU) }\end{array}$ & $59.98 \pm 4.10$ & $28.55 \pm 2.20$ & $23.23 \pm 1.37$ \\
\hline 4 & $\begin{array}{l}\text { Moringa oleifera } \\
\text { CU }\end{array}$ & $64.71 \pm 4.51$ & $29.69 \pm 2.06$ & $37.31 \pm 2.00$ \\
\hline 5 & $\begin{array}{l}\text { Telfaria } \\
\text { occidentalis } \mathrm{CU}\end{array}$ & $56.14 \pm 3.41$ & $14.13 \pm 1.70$ & $39.49 \pm 2.08$ \\
\hline 6 & $\begin{array}{l}\text { Manihot } \\
\text { esculenta } \mathrm{CU}\end{array}$ & $55.11 \pm 4.12$ & $30.84 \pm 1.87$ & $43.61 \pm 2.30$ \\
\hline 7 & MEAN & $58.76 \pm 4.84$ & $21.71 \pm 1.61$ & $33.87 \pm 2.23$ \\
\hline
\end{tabular}

130

131 Table 2-The Radioactivity Levels of ${ }^{226} \mathrm{Ra},{ }^{232} \mathrm{Th}$, and ${ }^{40} \mathrm{~K}$ in the Leafy Vegetables from Covenant University and Ibeshe of the leafy 132 vegetables

\begin{tabular}{|c|c|c|c|c|}
\hline $\mathbf{S} / \mathbf{N}$ & Sample codes & $\mathrm{Ra}^{-226}\left(\mathrm{Bqkg}^{-1}\right)$ & $\mathrm{Th}^{-232}\left(\mathrm{Bqkg}^{-1}\right)$ & $\mathrm{K}^{-40}\left(\mathrm{Bqkg}^{-1}\right)$ \\
\hline 1 & $\begin{array}{l}\text { Telfaria } \\
\text { occidentalis } \\
\text { (Ibeshe) }\end{array}$ & $2.44 \pm 0.47$ & $7.16 \pm 2.41$ & BDL \\
\hline 2 & $\begin{array}{l}\text { Corchorous } \\
\text { olitorus (Ibeshe) }\end{array}$ & $11.89 \pm 1.98$ & $3.95 \pm 0.76$ & BDL \\
\hline 3 & $\begin{array}{l}\text { Cnidoscolous } \\
\text { aconitifolius } \\
\text { (Ibeshe) }\end{array}$ & $0.75 \pm 0.25$ & $5.54 \pm 1.62$ & $191.06 \pm 14.05$ \\
\hline
\end{tabular}




\begin{tabular}{|c|c|c|c|c|}
\hline 4 & $\begin{array}{l}\text { Moringa oleifera } \\
\text { Ibeshe }\end{array}$ & BDL & $20.17 \pm 3.19$ & $709.88 \pm 48.97$ \\
\hline 5 & $\begin{array}{l}\text { Manihot } \\
\text { esculenta } \\
\text { (Ibeshe) }\end{array}$ & BDL & $0.81 \pm 0.32$ & $382.52 \pm 26.17$ \\
\hline \multirow[t]{2}{*}{6} & $\begin{array}{l}\text { Talicum } \\
\text { fruticosum } \\
\text { Ibeshe }\end{array}$ & $\mathrm{BDL}$ & $10.29 \pm 1.91$ & BDL \\
\hline & & $14.455 \pm 0.45$ & $7.98 \pm 1.70$ & $213.91 \pm 14.86$ \\
\hline 1 & $\begin{array}{l}\text { Telfaria } \\
\text { occidentalis } \mathrm{CU}\end{array}$ & $31.34 \pm 2.64$ & $7.58 \pm 1.92$ & $112.69 \pm 5.97$ \\
\hline 2 & $\begin{array}{l}\text { Corchorous } \\
\text { olitorius } \mathrm{CU}\end{array}$ & $\mathrm{BDL}$ & $9.81 \pm 2.24$ & $\mathrm{BDL}$ \\
\hline 3 & $\begin{array}{l}\text { Cnidoscolous } \\
\text { aconitifolius } \\
\text { (CU) }\end{array}$ & $14.12 \pm 2.09$ & $39.75 \pm 3.28$ & $133.82 \pm 7.08$ \\
\hline 4 & $\begin{array}{l}\text { Moringa oleifera } \\
\text { CU }\end{array}$ & $10.83 \pm 2.87$ & $\mathrm{BDL}$ & $654.29 \pm 42.64$ \\
\hline 5 & $\begin{array}{l}\text { Manihot } \\
\text { esculenta } \mathrm{CU}\end{array}$ & $14.01 \pm 1.83$ & $39.50 \pm 3.38$ & $939.30 \pm 49.70$ \\
\hline \multirow[t]{2}{*}{6} & $\begin{array}{l}\text { Talicum } \\
\text { fruticosum } \mathrm{CU}\end{array}$ & $\mathrm{BDL}$ & $14.32 \pm 4.19$ & $280.78 \pm 20.39$ \\
\hline & & $11.71 \pm 1.57$ & $18.49 \pm 2.50$ & $353.48 \pm 20.96$ \\
\hline
\end{tabular}

\subsection{Radiological Risks Assessments of the Vegetables and Soils from the Study Area}

135 In this study, Equation 1 was used to determine the absorbed dose rates from the obtained activity concentrations and the estimated

136 results. The mean value for CU soil is $60 \mathrm{nGyh}^{-1}$, which is higher than the recommended world average value, and as well the value for 137 Ibeshe plant. 
Determination of Radium equivalent activity in the samples in this research was estimated using equation 2 . Where $\mathrm{AC}_{\mathrm{RA}}$, $\mathrm{AC}_{\mathrm{TH}}$, and $A C_{K}$ are the activities concentration of ${ }^{226} \mathrm{Ra},{ }^{232} \mathrm{Th}$, and ${ }^{40} \mathrm{~K}$ measured in $\mathrm{Bqkg}$-1 respectively. The result of the radium equivalent activity obtained for the available soil and leafy vegetables varied between Ibeshe 12.75-76.26 Bqkg ${ }^{-1}$, mean was $28.37, \mathrm{CU}^{14} .10-142.82 \mathrm{Bqkg}^{-}$ ${ }^{1}$ mean was 392.34. Soil samples for Ibeshe were 35.45-97.93, the mean was 56.91 CU is 89.41-139.209 mean is 120.218 (Table 3). Calculation of hazard index from gamma ray dose to ${ }^{226} \mathrm{Ra},{ }^{232} \mathrm{Th}$, and ${ }^{40} \mathrm{k}$ could be estimated by equation 3 , which is the equation for calculating the external hazard index. ARA, $\mathrm{A}_{\mathrm{TH}}$, and $\mathrm{A}_{\mathrm{K}}$ are the average values of the activity concentrations ${ }^{226} \mathrm{Ra},{ }^{232} \mathrm{Th}$, and ${ }^{40} \mathrm{~K}$ in ${ }^{\text {Bqkg-1}}{ }^{1}$ respectively. The standard recommended for the $H_{e x}$ is a value less than one and at most equal to 1 . From the result obtained, the $\mathrm{H}_{\mathrm{ex}}$ varied between soil samples Ibeshe 0.0957-0.2645 and CU 0.1733-0.3757. The value for vegetables is from 0.0342-0.225 for Ibeshe and 0.0378-0.385 for CU. In this case, all the available leaf and soil samples considered for this parameter had acceptable values and within the acceptable standard. The estimated mean values were soil Ibeshe 0.154, CU was 0.3017 . Leafy vegetables for Ibeshe are 0.0819 and $\mathrm{Cu}$ is 0.1762 , respectively (Table 4).

The annual effective dose rate ranged between soil samples 19.19-52.54 mean 32.39, while CU was 48.06-936.882, while the mean is 213.055. Leafy vegetables, Ibeshe 7.622-196.224 mean is 83.17 while CU is 0.2027-71.24 while the mean is 39.56 . Gamma Index Estimation is engaged to calculating the hazard of $\gamma$-radiation because of the presence of natural radionuclide in the samples being investigated. Soil samples, Ibeshe $0.122-0.338$ while the mean is 0.197 , CU is $0.309-0.4816$ while the mean is 0.4147 . The leafy vegetables for Ibeshe are 0.0439-0.337 Ibeshe, mean is 0.1195, for CU, the range is from 0.049-0.512 while the mean is 0.240. Determination of Alpha Index, the estimation of the alpha index is another essential part of hazard measurement that qualifies the amount of alpha radiation due to random inhalation. For soil, Ibeshe $0.122-0.338$, the mean is 0.197 , CU is $0.309-0.4816$, and the mean is 0.4147 . For the leafy vegetables, Ibeshe is 0.0439-0.337, and the mean is 0.1195, while that of CU is 0.049-0.512 while the mean is 0.240 . The result of ${ }^{226} \mathrm{Ra},{ }^{232} \mathrm{Th},{ }^{40} \mathrm{~K}$ activity concentration of absorbed dose rate recorded by the Hypergermanium detector as a result of the background radiation from the soil samples at Ibeshe and Covenant University, the study areas in which the soil samples were collected. The mean for ${ }^{232} \mathrm{Th}$ ranged from $24.46 \mathrm{Bqkg}^{-1},{ }^{40} \mathrm{~K}_{\text {is }} 21.04 \mathrm{Bqkg}^{-1},{ }^{226} \mathrm{Ra}$ is $20.99 \mathrm{Bqkg}^{-1}$ for Ibeshe while that of $\mathrm{CU}$ is $34.69 \mathrm{Bqkg}{ }^{-1}$ for 
${ }^{232} \mathrm{Th}$, Ibeshe is $24.46 \mathrm{Bqkg}^{-1}$ while that of $\mathrm{CU}$ is $55.22 \mathrm{Bqkg}^{-1},{ }^{232} \mathrm{Th}$ at $\mathrm{CU}$ is higher than the recommended limit of 35.0 and 30.0 [28, 29].

${ }^{40} \mathrm{~K}$ is $26.06 \mathrm{Bqkg}^{-1}$ for $\mathrm{CU}$, while that of Ibeshe is $21.04 \mathrm{Bqkg}^{-1}$. ${ }^{226} \mathrm{Ra}$ is $34.69 \mathrm{Bqkg}^{-1}$. The limit of ${ }^{238} \mathrm{Ra}$ is $35.0 \mathrm{Bqkg}{ }^{-1}$, that of ${ }^{232} \mathrm{Th}^{3}$ $30.0 \mathrm{Bqkg}^{-1}$, and ${ }^{40} \mathrm{~K}$ is $500.0 \mathrm{Bqkg}^{-1}$ as recommended globally.

The following parameters were estimated for the soil samples for each study areas Radium Activity, External Radiation Hazards, Estimation of the annual effective dose rate, Activity Utilization index, Alpha index, Gamma Activity Index Representation, Excess Lifetime Cancer Risk (ELCR). The values of the gamma index ranged from 0.122-0.338 with a mean of 0.198 for Ibeshe, while that of CU is $0.309-0.457$, mean of 0.4014. Values greater than 1 should be avoided [27]. The representative gamma index, is correlated with the annual dose rate due to the excess external gamma radiation caused by superficial material. The estimated mean radium activity index for Ibeshe is 57.33 that of $\mathrm{CU}$ is $\mathbf{1 1 6 . 4 1 9}$. This parameter allows a single index to describe the gamma output in the background radiation from the radionuclides present in ${ }^{226} \mathrm{Ra},{ }^{232} \mathrm{Th},{ }^{40} \mathrm{~K}$ and must be $370 \mathrm{Bqkg}$ - 1 for to be safe for the populace. The annual effective dose rate for Ibeshe is $16.65 n G y h^{-1}$ to $42.84 n G y h^{-1}$, and the mean is $25.34 n G y h^{-1}$ while that of CU is $39.19 n G y h^{-1}$ to $74.22 \mathrm{v} n G y h^{-1}$ the mean is $55.68 n G y h^{-1}$, the mean is lower than the permissible limit of $59 n G y h^{-1}$. The mean annual effective dose rate for Ibeshe is $31.08 \mathrm{mSvy}^{-1}$, while that of CU is $68.29 \mathrm{mSvy}^{-1}$. The mean for ELCR for Ibeshe is 31.08 while that of CU is 239.03 , respectively is lower than the recommended limits of other published papers, [11], $\left(1.72 \times 10^{4}\right)$.

\section{Table 3 Radiological Parameters of the soil samples for Ibeshe and Covenant University}

\begin{tabular}{|c|c|c|c|c|c|c|c|c|c|c|}
\hline $\mathbf{S} / \mathbf{N}$ & SAMPLES & $\begin{array}{l}\text { Radium } \\
\text { Equivalent } \\
\text { Activity } \\
\text { Raeq }\end{array}$ & $\begin{array}{l}\text { External } \\
\text { Radiation }\end{array}$ & $\begin{array}{l}\text { Estimation of } \\
\text { the annual }\end{array}$ & $\begin{array}{l}\text { Calculation of the } \\
\text { external gamma } \\
\text { dose rate }\end{array}$ & $\begin{array}{l}\text { Activity } \\
\text { Utilization }\end{array}$ & $\begin{array}{l}\text { Alpha } \\
\text { Index }(\mathrm{I} \alpha)\end{array}$ & $\begin{array}{l}\text { Gamma } \\
\text { Activity }\end{array}$ & Index & $\begin{array}{l}\text { Excess } \\
\text { Lifetime }\end{array}$ \\
\hline
\end{tabular}




\begin{tabular}{|c|c|c|c|c|c|c|c|c|c|}
\hline & & & $\begin{array}{l}\text { Hazards } \\
\text { Hex }\end{array}$ & $\begin{array}{l}\text { effective dose } \\
\text { rate (AEDR) } \\
m S v y^{-1}\end{array}$ & $n G y h^{-1}$ & $\begin{array}{l}\text { Index } \\
\text { (AUI) }\end{array}$ & & $\begin{array}{l}\text { Representations } \\
\left(\mathrm{I}_{\mathrm{\gamma}}\right)\end{array}$ & $\begin{array}{l}\text { Cancer Risk } \\
\text { (ELCR) } \\
B^{\prime} q g^{-1}\end{array}$ \\
\hline 1 & $\begin{array}{c}\text { T.occidentalis } \\
\text { Ibeshe }\end{array}$ & 60.480 & 0.16336 & 32.560 & 26.549 & 24.024 & 0.116 & 0.208 & $0.113 \times 10^{-3}$ \\
\hline 2 & $\begin{array}{c}\text { C.olitorius } \\
\text { Ibeshe }\end{array}$ & 53.0673 & 0.1467 & 29.49 & 24.05 & 20.44 & 0.094 & 0.189 & $0.103 \times 10^{-3}$ \\
\hline 3 & $\begin{array}{c}\text { C.aconitifolius } \\
\text { Ibeshe }\end{array}$ & 39.764 & 0.1074 & 21.65 & 17.65 & 11.06 & 0.087 & 0.137 & $0.075 \times 10^{-3}$ \\
\hline 4 & $\begin{array}{c}\text { M.oleifera } \\
\text { Ibeshe }\end{array}$ & 35.451 & 0.0957 & 19.19 & 15.65 & 8.34 & 0.068 & 0.122 & $0.067 \times 10^{-3}$ \\
\hline 5 & $\begin{array}{c}\text { M.esculenta } \\
\text { Ibeshe }\end{array}$ & 97.933 & 0.2645 & 52.54 & 42.84 & 61.79 & 0.15 & 0.338 & $0.183 \times 10^{-3}$ \\
\hline 6 & $\begin{array}{c}\text { T.fruticosum } \\
\text { Ibeshe }\end{array}$ & 54.7407 & 0.1478 & 38.94 & 31.75 & 19.711 & 0.1035 & 0.189 & $0.136 \times 10^{-3}$ \\
\hline & MINIMUM & 35.451 & 0.0957 & 19.19 & 15.65 & 8.340 & 0.068 & 0.122 & $0.183 \times 10^{-3}$ \\
\hline & MAXIMUM & 97.933 & 0.2645 & 52.54 & 42.84 & 61.79 & 0.116 & 0.338 & $0.067 \times 10^{-3}$ \\
\hline & MEAN & 56.91 & 0.154 & 32.395 & 26.41 & 25.46 & 0.103 & 0.197 & $0.112 \times 10^{-3}$ \\
\hline 1 & $\begin{array}{c}\text { T. occidentalis } \\
\text { CU }\end{array}$ & 120.858 & 0.3264 & 64.68 & 52.74 & 94.62 & 0.19 & 0.417 & $0.226 \times 10^{-3}$ \\
\hline
\end{tabular}




$\begin{array}{ccccccccc}\text { Corchorous } & 139.209 & 0.3757 & 936.882 & 763.929 & 134.5710 & 0.1489 & 0.4816 & 3.279 \times 10^{-3} \\ \text { olitorius }(\mathrm{CU}) & & & & & & & \end{array}$

$\begin{array}{lllllllll}3 & \text { C.aconitifolius } & 114.909 & 0.1733 & 91.02 & 74.22 & 88.09 & 0.134 & 0.399\end{array}$

$(\mathrm{CU})$

$4 \quad$ Moringa

$132.131 \quad 0.3568 \quad 70.59$

57.56

$113.35 \quad 0.18$

$0.457 \quad 0.247 \times 10^{-3}$ oleifera $(C U)$

$5 \quad$ Manihot

$\begin{array}{lll}124.791 & 0.3370 & 67.10\end{array}$

54.72

$100.68 \quad 0.218$

0.425

$0.234 \times 10^{-3}$

esculenta

(CU)

6 T.fruticosum

$89.410 \quad 0.2412 \quad 48.06$

39.19

43.25

0.14

0.309

$0.168 \times 10^{-3}$

(CU)

MINIMUM

89.410

(0.1733

48.06

39.19

$43.25 \quad 0.134$

0.309

$0.318 \times 10^{-3}$

MAXIMUM $\quad 139.209$

$\begin{array}{lll}0.3757 & 936.882 & 763.929\end{array}$

$134.5710 \quad 0.218$

$0.4816 \quad 3.27 \times 10^{-3}$

MEAN

120.218

$0.3017 \quad 213.055$

173.726

95.76

0.1684

0.4147

$0.745 \times 10^{-3}$

177

178

179

180

181 
Table 4 Radiological Parameters of the leafy vegetables samples for Ibeshe and Covenant University

\begin{tabular}{|c|c|c|c|c|c|c|c|c|c|}
\hline $\mathbf{S} / \mathbf{N}$ & SAMPLES & Radium & External & Estimation & Calculation & Activity & Alpha & Gamma & Excess Lifetime \\
\hline & & $\begin{array}{c}\text { Equivalent } \\
\text { Activity } \\
\mathbf{R a}_{\mathrm{e}} \\
\\
\mathrm{q}\end{array}$ & $\begin{array}{l}\text { Radiation } \\
\text { Hazards } \\
\mathbf{H}_{\mathrm{ex}}\end{array}$ & $\begin{array}{l}\text { of the } \\
\text { annual } \\
\text { effective } \\
\text { dose rate } \\
\text { (AEDR) } \\
m S v y^{-1}\end{array}$ & $\begin{array}{l}\text { of the } \\
\text { external } \\
\text { gamma } \\
\text { dose rate } \\
\quad n G y h^{-1}\end{array}$ & $\begin{array}{l}\text { Utilization } \\
\text { Index } \\
\text { (AUI) }\end{array}$ & $\begin{array}{l}\text { Index } \\
\text { (I } \alpha)\end{array}$ & $\begin{array}{l}\text { Activity Index } \\
\text { Representations } \\
\left(\mathrm{I}_{\gamma}\right)\end{array}$ & $\begin{array}{l}\text { Cancer Risk } \\
\text { (ELCR) } \\
B q k g^{-1}\end{array}$ \\
\hline 1 & $\begin{array}{c}\text { T.occidentalis } \\
\text { Ibeshe }\end{array}$ & 12.7558 & 0.0342 & 87.523 & 71.366 & 1.1443 & 0.0122 & 0.04393 & $0.306 \times 10^{-3}$ \\
\hline 2 & $\begin{array}{l}\text { C.olitorius } \\
\text { Ibeshe }\end{array}$ & 17.6095 & 0.0473 & 54.2583 & 44.242 & 3.1394 & 0.01975 & 0.05938 & $0.189 \times 10^{-3}$ \\
\hline 3 & $\begin{array}{c}\text { C.aconitifolius } \\
\text { Ibeshe }\end{array}$ & 18.866 & 0.0631 & 102.208 & 83.34 & 73.63 & 0.0277 & 0.09388 & $0.357 \times 10^{-3}$ \\
\hline 4 & $\begin{array}{c}\text { M.oleifera } \\
\text { Ibeshe }\end{array}$ & 76.26 & 0.225 & 51.23 & 41.78 & 1015.9 & 0 & 0.337 & $0.179 \times 10^{-3}$ \\
\hline 5 & $\begin{array}{c}\text { M.esculenta } \\
\text { Ibeshe }\end{array}$ & 30.612 & 0.08265 & 196.224 & 160.00 & 292.65 & 0.00405 & 0.13155 & $0.686 \times 10^{-3}$ \\
\hline 6 & \begin{tabular}{l}
\multicolumn{1}{c}{$T$} \\
fruticosum \\
Ibeshe
\end{tabular} & 14.71 & 0.0397 & 7.622 & 6.215 & 2.117 & 0 & 0.0514 & $0.026 \times 10^{-3}$ \\
\hline & MINIMUM & 12.7558 & 0.0342 & 7.622 & 6.215 & 2.117 & 0.0040 & 0.04393 & $0.686 \times 10^{-3}$ \\
\hline
\end{tabular}




\begin{tabular}{|c|c|c|c|c|c|c|c|c|c|}
\hline & MAXIMUM & 76.26 & 0.225 & 196.224 & 160.00 & 292.65 & 0 & 0.13155 & $0.026 \times 10^{-3}$ \\
\hline & MEAN & 28.37 & 0.0819 & 83.17 & 67.82 & 231.43 & 0.0106 & 0.1195 & $0.291 \times 10^{-3}$ \\
\hline 1 & $\begin{array}{l}\text { T.ocidentalis } \\
\text { (CU) }\end{array}$ & 50.85 & 0.137 & 29.127 & 23.75 & 47.97 & 0.1567 & 0.179 & $0.101 \times 10^{-3}$ \\
\hline 2 & $\begin{array}{c}\text { C. olitorius } \\
\text { (CU) }\end{array}$ & 14.1053 & 0.0378 & 7.2667 & 5.92524 & 1.9247 & 0 & 0.04905 & $0.0254 \times 10^{-3}$ \\
\hline 3 & $\begin{array}{c}\text { C.aconitifolius } \\
\text { (CU) }\end{array}$ & 81.26 & 0.219 & 44.28 & 36.11 & 71.40 & 0.0706 & 0.290 & $0.154 \times 10^{-3}$ \\
\hline 4 & $\begin{array}{c}\text { Moringa } \\
\text { oleifera }(C U)\end{array}$ & 61.210 & 0.1652 & 0.2027 & 0.1652 & 858.53 & 0 & 0.25419 & $\begin{array}{c}0.007094 \times 10^{-} \\
3\end{array}$ \\
\hline 5 & $\begin{array}{c}\text { M. esculenta } \\
\text { (CU) }\end{array}$ & 142.82 & 0.385 & 85.22 & 69.49 & 1799.69 & 0.07 & 0.512 & $0.298 \times 10^{-3}$ \\
\hline 6 & $T$ & 42.097 & 0.1136 & 71.2407 & 58.089 & 161.77 & 0.0716 & 0.16151 & $0.249 \times 10^{-3}$ \\
\hline & $\begin{array}{c}\text { Fruticosum } \\
\text { CU }\end{array}$ & & & & & & & & \\
\hline & MINIMUM & 14.1053 & 0.0378 & 0.2027 & 0.1652 & 1.9247 & 0.0706 & 0.0490 & $0.298 \times 10^{-3}$ \\
\hline & MAXIMUM & 142.82 & 0.219 & 85.22 & 69.49 & 858.53 & 0 & 0.512 & $\begin{array}{l}0.007094 \times 10^{-} \\
3\end{array}$ \\
\hline & MEAN & 392.34 & 0.1762 & 39.56 & 36.29 & 490.21 & 0.061 & 0.240 & $0.138 \times 10^{-3}$ \\
\hline
\end{tabular}


184 In this study, we measured the activity concentrations for natural radioactive nuclides ${ }^{226} \mathrm{Ra},{ }^{232} \mathrm{Th},{ }^{40} \mathrm{~K}$ in leafy vegetables and soil samples collected from Ibeshe and Covenant University areas of Ogun State. The activity concentration ranged from ${ }^{226} \mathrm{Ra},{ }^{232} \mathrm{Th}$, and ${ }^{40} \mathrm{~K}$ in soils were calculated. The mean value for the absorbed rate concentration results shows that, the mean concentration of ${ }^{226} \mathrm{Ra}$, ${ }^{232} \mathrm{Th},{ }^{40} \mathrm{~K}$ in the agricultural soil was for ${ }^{232} \mathrm{Th} 24.18 \pm 2.31,{ }^{40} \mathrm{~K} 20.93 \pm 2.27,{ }^{226} \mathrm{Ra} 20.95 \pm 1.9$ for Ibeshe and ${ }^{232} \mathrm{Th}^{58.76} \pm 4.84 \mathrm{Bqkg}{ }^{-1}$, ${ }^{40} \mathrm{~K} 26.06 \pm 1.93 \mathrm{Bqkg}^{-1},{ }^{226} \mathrm{Ra}_{33.87} \pm 2.23 \mathrm{Bqkg}^{-1}$ respectively. And that of the leafy vegetables was ${ }^{226} \mathrm{Ra} 5.02 \pm 0.9,{ }^{232} \mathrm{Th} 7.98 \pm 1.70$

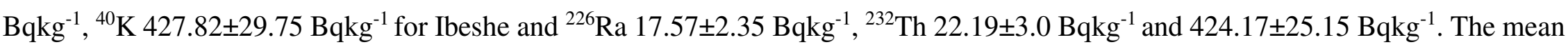
values for $\mathrm{CU}$ soil for ${ }^{232} \mathrm{Th}$ were higher than the World average standard values of $35 \mathrm{Bqkg}^{-1}$. Significantly, the statistical analysis presented in this study indicates that the absorption of radionuclide in different plants depends on the background radionuclide concentrations, absorption mechanism in plants, and sorption ability in aqueous phase. This study can be used as a template for the Ministry of Agriculture and Ministry of Environment and other agencies such as Federal Environmental Protection Agency, National Environmental Standards and Regulations Enforcement Agency, to monitor the radiological impact on the soil and other crops that share the soil features in Nigeria and beyond. In addition, this research provided more information on solution to the Goal 15 of the Sustainable Development Goals on the protection, restoration of the sustainable use of ecosystem, i.e., the plants and soils.

Acknowledgment: The authors acknowledge God for inspiration to carry out this work, Research and Development grant by the assistance and support to publish the work.

201

\section{DECLARATIONS}


Funding: This research work was supported by the Research and Development grant for Atmospheric Chemistry and Environment Research ACER project made available by the Centre for Atmospheric Research, National Space Research and Development Agency, Anyigba, Nigeria.

Conflict of Interest: The authors declare no conflict of interest.

\section{REFERENCES}

1. Adagunodo TA, George AI, Ojoawo IA, Ojesanmi K, Ravisankar R. Radioactivity and radiological hazards from a kaolin mining field in Ifonyintedo, Nigeria. Methods. 2018; 5: 362-374.

2. Ademola AK, Hammed OS, Adejumobi CA. Radioactivity and dose assessment of marble samples from Igbeti mines, Nigeria. Radiat Protect Dosim. 2008; 132 (1):94-97.

3. Ademola, JA. Radionuclide content of concrete building blocks and radiation dose rates in some dwellings in Ibadan. Nigeria. $J$ Environ Radioact. 2005; 81:107-113.

4. Ajayi JO, Balogun BB, Olabisi O. Natural radionuclide contents in raw materials and the aggregate finished product from Dangote Cement plc, Obajana, Kogi state, North Central Nigeria. Res J Environ Earth Sci. 2012; 4 (11): 959-961, 2012 ISSN: 2041- 0492.

5. Ajayi OS, Ajayi IR. A survey of environmental gamma radiation levels of some areas of Ekiti and Ondo states, southwestern Nigeria. Niger J Phys. 1999;11 (15):17-21.

6. Akinloye, MK, Olomo, JB, Olubunmi, PA. Meat and poultry consumption contribution to the natural radionuclide intake of the inhabitants of the Obafemi Awolowo University, Ile-Ife, Nigeria. Nucl Instrum Methods Phys Res A: Accelerators, Spectrometers, Detectors and Associated Equipment. 1999; 422(1-3): 795-800.

7. Akinyose FC, Tchokossa P, Orosun MM, Oluyde SO, Umakha M, Ochommadu KK, Olaniyan, TA, Ajibade OA. Radiological impacts of natural radioactivity in locally produced tobacco products in ibadan, Oyo state, Nigeria. SINET. 2018 ; 10 (1):59-75. 
8. Avwiri, GO, Ononugbo, CP, Nwokeoji, IE. Radiation Hazard Indices and Excess Lifetime cancer risk in soil, sediment and water around mini-okoro/oginigba creek, Port Harcourt, Rivers State, Nigeria. Comprehensive Journal of Environment and Earth Sciences. 2014; 3(1): 38-50.

9. DeForest DK, Toll JE, Judd NL, Amy Shaw K, McPeek, KT, Santore RC. Sediment toxicity data and excess simultaneously extracted metals from field-collected samples: Comparison to United States Environmental Protection Agency benchmarks Integr Environ Assess Manag 2022; 18:174-186. 2021 SETAC

10. European Commission. Radiation Protection 112, Radiological protection principles concerning the natural radioactivity of building materials, Brussels, European Commission. 1999.

11. Farai IP, Ademola JA. Population dose due to building materials in Ibadan, Nigeria. Radiat Prot Dosim. 2001; 95:69-73.

12. Giri S, Singh G, Jha VN, Tripathi RM. Risk assessment due to ingestion of natural radionuclides and heavy metals in the milk samples: a case study from a proposed uranium mining area. Jharkhand. Environ Monit Assess. 2011; 175 (1-4): 157-166.

13. Giri RR, Ozaki H, Takayanagi Y, Taniguchi S, Takanami R. Efficacy of ultraviolet radiation and hydrogen peroxide oxidation to eliminate large number of pharmaceutical compounds in mixed solution. Int J Environ Sci Technol. 2011; 8 (1): 19-30.

14. Isinkaye OM, Jibiri NN, Olomide AA. Radiological health assessment of natural radioactivity in the vicinity of Obajana cement factory, North Central Nigeria. J Med Phys. 2015; 40 (1): 52-59.

15. Jibiri NN, Esen NU. Radionuclide contents and radiological risk to the population due to raw minerals and soil samples from the mining sites of quality ceramic and pottery industries in Akwa Ibom, Nigeria. Radioprotection. 2011; 46 (1):75-87.

16. Joel ES, Adewoyin OO, Omeje M, Olawole CO, Zaidi E, Khalis MAK. Radioisotopes RA-226 TH-232, K-40 Concentration in the imported marbles used for building purposes in Nigeria. Int. J. Civ. 2018; 9(11): 2986-2998.

17. Obed RI, Farai IP, Jibiri NN. Population dose distribution due to soil radioactivity concentration levels in 18 cities across Nigeria. J Radiol Prot. 2005; 25: 305-312. 
18. Olabode SO, Mohammed MZ. Depositional facies and sequence stratigraphic study in parts of Benin (Dahomey) Basin SW Nigeria: implications on the re-interpretation of tertiary sedimentary successions. Int. J. Geosci. 2016; 7(02): 210.

19. Olurin K, Okafor J, Alade A, Asiru R, Ademiluwa J, Owonifari K, Oronaye O. Helminth parasites of Sarotherodon galilaeus and Tilapia zillii (Pisces: Cichlidae) from River Oshun, Southwest Nigeria. Int. J. of Aquatic Science. 2012; 3(2), 4955.

20. Omeje M, Adewoyin OO, Joel ES, Ehi-Eromosele CO, Emenike CP, Usikalu MR, Akinwumi, SA, Zaidi, Mohammad AS. Natural radioactivity concentrations of ${ }^{226} \mathrm{Ra},{ }^{232} \mathrm{Th}$, and ${ }^{40} \mathrm{~K}$ in commercial building materials and their lifetime cancer risk assessment in Dwellers. Human Ecol Risk Assess. 2018; 24(8): 2036-2053.

21. Onumejor CA, Akinpelu A, Arijaje TE, Usikalu MR, Oladapo OF, Emetere ME, Omeje M, Achuka JA. Monitoring of Background Radiation in Selected Schools in Ota, Ogun State Nigeria by Direct measurement of terrestrial radiation dose rate. IOP Conf Ser Earth Environ Sci. 2019; 331:012038.

22. Orosun MM, Lawal TO, Akinyose FC. Natural radionuclide concentrations and radiological impact assessment of soil and water in Tanke-Ilorin, Nigeria. ZJST. 2016; 11:158-172.

23. Orosun MM, Lawal TO, Ezike SC, Salawu NB, Atolagbe BM, Akinyose FC, Ige SO, Martins G. Natural radionuclide concentration and radiological impact assessment of soil and water from Dadinkowa Dam, Northeast Nigeria. JNAMP. 2017 ; 42 (1): 307-316.

24. Orosun MM, Usikalu MR, Oyewumi KJ, Adagunodo AT. Natural radionuclides and radiological risk assessment of granite mining field in Asa, North-central Nigeria. Methods. 2019; 6:2504-2514.

25. Orosun, MM, Alabi AB, Olawepo AO, Orosun RO, Lawal TO, Ige SO. Radiological safety of water from Hadejia river. In IOP Conference Series: Earth and Environmental Science. 2018; 173 (1): 012036).

26. Ramasamy V, Senthil S, Meenakshisundaram V, Gajendran V. Measurement of natural radioactivity in beach sediments from north east coast of Tamilnadu, India. Res J Appl Sci Eng Tech. 2009; 1(2): 45-58. 
27. Taskin HM, Karavus P, Ay A, Touzogh S, Hindiroglu, Karaham, G. Radionuclide concentration in soil and lifetime cancer risk due to the gamma radioactivity in Kirklareli. Turkey. J. Environ. Radioact. 2009; 100(1): 49-53.

28. United State Environmental Protection Agency "EPA" (2018) Granite-countertops-and radiation. Updated on 3rd December, 2018 and accessed on 15th February, 2019. Available at: https://www.epa.gov/radiation/granite-countertops-and-radiation.

29. UNSCEAR (2000) “Sources, Effects and Risks of Ionization radiation”, United Nations Scientific Committee on the Effects of Atomic Radiation. Report to the General Assembly, with Scientific Annexes B: Exposures from Natural Radiation Sources NewYork.

30. Usikalu MR, Fuwape IA, Jatto SS, Awe OF, Rabiu AB, Achuka JA. Assessment of radiological parameters of soil in Kogi State, Nigeria. Environ. Forensics. 2017; 18 (1): 1-14.

31. Usikalu MR, Maleka PP, Malik M, Oyeyemi KD, Adewoyin OO. Assessment of geogenic natural radionuclide contents of soil samples collected from Ogun State, South western, Nigeria. Int J Radiat Res. 2016;14 (3): 355-361.

32. Usikalu MR, Oderinde A, Adagunodo TA, Akinpelu A. Radioactivity concentration and dose assessment of soil samples in cement factory and environs in Ogun state, Nigeria. Int. J. Civ. Eng. Technol. 2018; 9 (9):1047-1059.

33. Usikalu MR, Onumejor CA, Akinpelu A, Achuka JA, Omeje M, Oladapo OF. Natural radioactivity concentration and its health implication on dwellers in selected locations of Ota. IOP Conf Ser Earth Environ Sci. 2018; 173: 012005.

34. Xinwei L, Zhang X. Measurements of natural radioactivity in sand collected from the Baoji Weihe sands park, China. Environ Geo. 2006; 50: 977-982. 